\title{
Public Service Quality in Administration in Kalidoni Kelurahan Office, Palembang City
}

Femi Asteriniaha*

${ }^{a}$ Undergraduate Program, Department of Public Administration, University of Social and Political Science (STISIPOL) Candradimuka Palembang, Indonesia

\section{ARTICLE INFORMATION}

\section{Article history:}

Data submission : 12 June 2020

$1^{\text {st }}$ revision: 11 August 2020

Accepted: 16 November 2021

Available online: 10 December 2021

Keywords: public service, quality of service, administration sector

\begin{abstract}
This reseach aims to examine service quality of Kalidoni urban village Office, Palembang City, the supporting and inhibiting factors of service at Kalidoni village office, Palembang City. This research used a qualitative approach with a descriptive level of explanation. Data or information is collected through informant interviews. The results showed that based on the Tangible dimension (physical evidence), the availability of facilities and infrastructure to support the convenience of services such as waiting rooms, parking lots, toilets, prayer rooms, suggestion boxes, and service counters at Kalidoni village office, Palembang City Based on the dimension of reliability, service procedures are a little indifferent due to improper turnaround time. Based on the dimension of Responsiveness, officers do not give a positive response to community complaints, and there is no follow-up to the criticisms and suggestions submitted. Based on the dimension of Assurance, there is still a delay in the process of completing the services provided that are not in accordance with the existing standard operating procedures because there are still people who do not complete the required requirements, so they are required to complete these requirements to be able to continue the procedure. Empathy dimension (Empathy), the lack of attention given by the officers and the lack of hospitality received by the community are complaints that are often raised by the public.
\end{abstract}

2021 FIA UB. All rights reserved.

\section{Introduction}

Public services are all activities in order to fulfil basic needs in accordance with the basic rights of every citizen or resident of goods, services and administrative services provided by service providers related to the public interest. Examples of public services in the form of administrative services are making legalization of citizen identity card, family card, licensing services, certificate of business, land certificate and other certificates. Service quality is a condition in which a dynamic relationship is created between users and service providers, both services and humans. Public services are closely related to capability, responsiveness, timeliness, and available infrastructure. If the services provided are in accordance with what is expected by service users, it can be said that the service is a quality service.

Conversely, if the services provided are not in accordance with the expectations of service users, it can be said that the services are not of high quality. Good or bad service quality is not based on the point of view or perception of the service provider but based on consumer perceptions and rules or regulations regarding service quality. Public services provided by government agencies have not been able to meet the quality expected by the community. This is indicated by the existence of various public 
complaints regarding service discrimination. For example, there are people who are made difficult when applying for citizen registration card in government agencies such as being charged extra fees to get faster service. In addition, other complaints expressed by service users were the uncertainty of time which resulted in low service quality. Time uncertainty can lead to a bad image of these government agencies.

The community certainly wants to get a good quality service from the government. Quality service or what is commonly referred to as excellent service is the best service that meets quality service standards. Based on preliminary observations made by the author at Kalidoni urban village office, Palembang City, in carrying out its function of serving the community, it is felt that it is still not in accordance with the minimum service standards. If referring to indicators; speed, accuracy, friendliness and comfort are still low. The author finds problems related to public services.

First, problems related to public services, namely regarding the length of service, for example when the community wants to take care of making a family card. The community conveyed that the process of making a family card was not in accordance with the supposed timeframe of three days. Can only be completed within a week or more.

The second problem, regarding the friendliness of employees at the district office to service users who come. This unfriendliness can be seen when employees who do not smile to service users, officers who chat with other officers discuss problems that are not related to the services provided so that people who are receiving services are not served properly. In addition, the authors found an employee response who was not responsive to the community who wanted to provide services and did not understand service procedures. Unresponsiveness greatly disturbs the quality of service felt by people who come and want to get good service.

Based on the identification of these problems, the problem formulations in this study are how is the quality of public services at Kalidoni urban village office, Palembang City?

\section{Theory}

According to Zeithaml et al. (in Hardiansyah 2011) to find out the quality of service that is perceived by consumers, there are indicators of service quality located in five dimensions of service quality, namely:

1. Tangible or physical evidence, namely the ability to show its existence to external parties. It means that the appearance and capability of physical facilities and infrastructure and the condition of the surrounding environment are tangible evidence of the services provided.

2. Reliability or reliability, is the ability to provide services as promised accurately and reliably.

3. Responsiveness or response, is a willingness to help and provide fast and appropriate services to the community by conveying clear information.

4. Assurance, or assurance and certainty, namely knowledge, politeness, and the ability of employees to foster a sense of trust in customers. Consists of several components, including communication, credibility, security, competence and courtesy.

5. Empathy which is giving sincere and individual or personal attention to customers by trying to understand customer desires.

Administration in a narrow sense revolves around various administrative activities. Administrative activities are a very important part of organizational activities, especially because these activities involve handling information that is said to play a role as "blood" for an organization.

Administration in a broad sense means the whole process of carrying out activities based on certain rationale by two or more people in the context of achieving a predetermined goal by using certain facilities and infrastructure as well.

The scope of administrative duties in this office can be said to be service tasks around tangible information (Barata, 2003), namely:

1. Collecting namely: activities to seek and seek the availability of all information that previously did not exist or scattered everywhere so that it is ready to be used when needed.

2. Recording namely: activities that affix with various writing equipment the information needed so that it is in the form of writing that can be read, sent and stored.

3. Managing namely: various activities working on information with the intention of presenting it in a useful form.

4. Sending namely: activities that save by sharing means and tools from one party to another.

5. Saving Namely: the activity of putting in various ways and tools in certain safe places.

\section{Research Method}

This study uses a qualitative approach with the consideration that in this study the researcher intends to gain a deep understanding of the quality of public services in the administrative sector at Kalidoni 
village office, Palembang City. The method or approach used is a qualitative method.

This research uses a qualitative approach. According to Sugiyono (2013), qualitative descriptive research is aimed at describing and describing existing phenomena, both natural and human engineering, which pay more attention to characteristics, quality, linkages between activities. In addition, descriptive research does not provide treatment, manipulation or alteration of the variables under study, but rather describes a condition as it is.

The variable in this study is an independent variable, namely "Quality of public service in the administration sector at Kalidoni Urban Village Office, Palembang City ". This variable is independent because it is not associated with other variables. In line with this, which is the focus of this study is the Quality of Public Services in the field of administration at the village office Kalidoni Palembang analysed via tangible or physical evidence, reliability or reliability, responsiveness or response, assurance or guarantee, empathy the operational definitions used to see quality of public services in the administration sector at Kalidoni urban village office of Palembang City using the theory of Zeithaml et al. (in Hardiansyah, 2011).

The units of analysis in this study are: (1) Public service: An activity or series of activities in order to fulfill the need for services in accordance with the statutory regulations for every citizen and resident for goods, services and / or administrative services provided by public service providers. (2) Administration: The whole process of carrying out activities based on a certain rationale by two or more people in the framework of a predetermined goal by using certain facilities and infrastructure as well

The informants in this study were determined based on their abilities / capabilities, namely that the parties really understood the problem appointed in this study. As for those who will be used as informants in this study consist of the head of Kalidoni village, the of public service staff, general service section staff, and community service users. The data used in this study comes from primary data, namely data from interviews and secondary data from documents and reports. The data collection technique used in this research is to use the interview method, observation and literature study. Data analysis in this study will use an interactive model from Miles et al. (2014) which includes four components of analysis, namely data collection, data condensation, data display and a conclusion.

\section{Results}

Services for legalization of identity cards, family cards, building construction permits, moving information, land, community logging permits, crowd permits, legalization of letters, and family hope programs, at Kalidoni urban village office, Palembang City are part of the tasks carried out by the sub-district government apparatus in the field of administration. In carrying out public services, especially family card and citizen registration card services in Kalidoni village, it is regulated in Law Number 23 of 2006 concerning population administration. To find out the quality of public services in Kalidoni Village, Palembang City.

The availability of facilities and infrastructure to support the convenience of services such as waiting rooms, parking lots, toilets, prayer rooms, suggestion boxes, and service counters at Kalidoni urban village office, Palembang City. The community already understands the information on requirements and procedures that have been given by officers well, it's just that the service procedure is a little disrupted due to the long completion time. The officers did not give a positive response to community complaints, and there was no follow-up to the criticisms and suggestions submitted.

Security guarantees are guaranteed because there are Satpol PP officers who are always on guard to provide a sense of security to everyone who comes. There are still obstacles in the process of time the completion of services provided that are not in accordance with the existing standard operating procedures because there are still people who do not complete all the requirements needed, so they are obliged to complete these requirements to be able to continue the procedure.

Lack of attention given by officers and lack of hospitality received by the community are complaints that are often raised by the public. Considering that the main function of the government is to serve the community, the government needs to continue to strive to improve the quality of service. Local government agencies such as sub-districts are one example of government agencies that carry out public services, namely the village, as a public service provider having the main task of assisting the head of sub-district in administering governance, development and society in the village area as well as increasing the effectiveness of public services in the framework of good governance. governance) as well as improving the quality of services in the form of services or licensing through transparency and standardization of services.

The implementation of quality public services requires the support of human resources, namely 
employees or employees who are ready and reliable because employees are the parties who provide public services, especially when dealing directly with the community, consumers, and customers. In fact, it took longer and even more than one week, so that service recipients often complained about the conditions that occurred.

\section{Discussion and conclusion}

Based on the results of this study, several things can be gathered regarding the quality of public services in the field of population administration at Kalidoni urban village office, Palembang City. The condition of available facilities related to convenience has been fully fulfilled by the Suak Tapeh district office. As well as Kalidoni urban village office service counter, it has been noticed that many people praise this availability.

The community already understands the information that has been given from the service officer and the procedures provided by the service officer are good, but a little disturbed due to the long time to complete the service. The response given by officers in receiving complaints is less responsive and does not focus on community complaints, so that people who have problems feel neglected by the attitude of the officers. As well as the response of officers to the criticism and suggestions given is not good due to the absence of follow-up on suggestions and criticisms given by the community.

In terms of security, it can be said that the security in Kalidoni urban village office of Palembang is good. However, Kalidoni urban village, Palembang City, has not implemented the service time properly because there is no guarantee or time certainty for the length of the process of completing a service, even though it is said that it has implemented the time according to the procedures. The lack of attention of officers to the community is one of the complaints that is often raised by the community in getting services. The friendliness provided by officers is still very minimal, making the recipients uncomfortable with these conditions.

From the conclusions put forward, the authors try to provide suggestions in an effort to improve the quality of public services at Kalidoni Village, Palembang City, as follows:
1. It is necessary to budget for additional waiting chairs for the community because when it is crowded there are some people who do not get seats.

2. There must be socialization to the community to further increase understanding so that in the future there is no such thing as a lack of required documents when they want to follow service procedures.

3. In terms of the response of officers in receiving complaints, suggestions and criticisms, it is necessary to pay more attention to the direction of officers in correct service procedures not only in carrying out the service process but also having to respond to every complaint, suggestion, and criticism that comes in. because this concerns the community's satisfaction in receiving services so that the impression you get is not only the service that completes the service but also the satisfying and maximum service.

4. There must be an emphasis on discipline in applying the time to complete the services provided so that it is in accordance with the existing operational standards for each type of service so that the community does not feel cheated or mocked by a timely description of the service.

5. In terms of attention and friendliness of officers in serving the community, more attention must be given because seen from the results of the previous interview, it could be said that the officers were lacking attention and friendliness, for that the officers had to pay extra attention in serving every community who came without differentiating who was involved. will be served but whatever can be served.

\section{References}

Barata, A.A. (2003) Dasar- Dasar Pelayanan Prima. Elex Media Kompetindo.

Hardiyansyah. (2011). Kualitas Pelayanan Publik Konsep, Dimensi, Indikator, dan Implementasinya. Gava Media.

Sugiyono. (2013). Metode Penelitian Pendidikan Pendekatan Kuantitatif, Kualitatif dan $R \& D$. Alfabeta. 